Copyright (C) 2020 University of Bucharest Printed in Romania. All rights reserved

ISSN print: $1224-5984$

ISSN online: $2248-3942$
Rom Biotechnol Lett. 2020; 25(6): 2127-2131 doi: $10.25083 / \mathrm{rbl} / 25.6 / 2127.2131$

Received for publication, May, 17, 2020

Accepted, July, 30, 2020

Original paper

\title{
An Atypical Case of Cluster Convulsions with Gastroenteritis in a child harboring a likely benign heterozygous variant of the NTRK2 gene
}

\author{
EVELINA CARAPANCEA ${ }^{1,2}$, EUGENIA ROZA ${ }^{1,2,4}$, FLORINA MIHAELA \\ NEDELEA $^{3}$, MARIA PUIU ${ }^{4}$, RALUCA IOANA TELEANU ${ }^{1,2}$ \\ 1“Dr. Victor Gomoiu” Children's Hospital, Bucharest, Romania \\ 2"Carol Davila" University of Medicine and Pharmacy, Bucharest, Romania \\ ${ }^{3}$ Filantropia Clinical Hospital, Bucharest, Romania \\ 4"Victor Babes" University of Medicine and Pharmacy, Timisoara, Romania
}

\begin{abstract}
Convulsions in the context of mild diarrhea were first described in 1982 by Morooka K. There is a description of seasonal, etiological and age distribution of cases. The role of genetic involvement in the mechanism of $\mathrm{CwG}$ is not yet well understood. In this report we present a case of a 3-year-old boy with convulsions with mild gastroenteritis and "de novo" heterozygous variant in NTRK2 gene that was classified as benign. The clinical context with developmental delay and dysmorphic features suggests, however, a possible genetic cause in this case. Further comprehensive re-evaluation of sequencing data, possibly with additional clinical information, is advised.
\end{abstract}

Keywords Convulsions, gastroenteritis, WES, NTRK2 gene.

To cite this article: CARAPANCEA E, ROZA E, NEDELEA FM, PUIU M, TELEANU RI. An Atypical Case of Cluster Convulsions with Gastroenteritis in a child harboring a likely benign heterozygous variant of the NTRK2 gene. Rom Biotechnol Lett. 2020; 25(6): 2127-2131. DOI: $10.25083 / \mathrm{rbl} / 25.6 / 2127.2131$ 


\section{Introduction}

Convulsions in the context of mild diarrhea were first described in 1982 by Morooka K (MOROOKA K, 1982 [1]). Afterwards, most cases were reported in Japan, Hong Kong, Taiwan (NISHIMURA et al, 2002 [2], KOMORI et al, 1995 [3], UEMURA et al, 2002 [4]), The United States (IYADURAI et al, 2007 [5]) and Europe - Great Britain (NARCHI H, 2004 [6]). Convulsions with mild gastroenteritis $(\mathrm{CwG})$ in children are characterized by: $(\mathbf{1})$ previously healthy infants and young children aged 6 months to 3 years presenting with afebrile generalized convulsions associated with symptoms of gastroenteritis; (2) afebrile seizures occurring sometimes in clusters; (3) normal laboratory examination results including electrolytes, blood glucose and cerebrospinal fluid; (4) normal intercritical electroencephalographic recordings and (5) good prognosis, with seizure freedom and normal development (KOMORI H et al, 1995 [3]).

\section{Literature review}

There is a description of seasonal distribution of cases, predominantly from November to May, during the cold season (UEMURA N, 2002 [4], NARCHI H, 2004 [6], MA X et al, 2018 [7]). However, there are reports that specify a seasonal difference between rotaviral and noroviral infections, the former being more prevalent from January to May, the latter during November and December (RAM KIM B et al, 2018 [8], KAWANO G, 2007 [9], VERROTTI A, 2011 [10]). Fang et al examined the characteristics of Norovirus infection in patients who associated convulsions caused by gastroenteritis between 2006 and 2015. They found no seasonal predilection except the winter season of 2006-2007 (FANG Y, 2006 [11]).

This condition typically occurs in previously healthy children. The age range has been estimated in the literature between 1 month and 6 years (UEMURA N et al, 2002 [4], KAWANO G et al, 2007 [9], VERROTTI A et al, 2011 [10], VERROTTI A et al, 2009 [12], TANABE T et al, 2011 [13], CHEN B et al, 2018 [14], LI T et al, 2014 [15], UEDA $H$ et al, 2015 [16], VERROTTI A et al, 2014 [17], HYUN S et al, 2015 [18], KIM G et al, 2016 [19], BEN K et al, 2014 [20], CASTELLAZZI L et al, 2016 [21], OKUMURA A et al, 2004 [22], NARCHI H, 2004 [6], CHEN S et al, 2009 [23]). Usually, psychomotor development is normal before and after the onset of seizures. Some authors described an equal distribution among genders while others indicated either a boy or girl predominance. For example, noroviral infection seems to affect a higher percentage of girls - between $55 \%$ and $60 \%$ (RAM KIM B et al, 2018 [8], KAWANO G et al, 2007 [9], KIM G et al, 2016 [19], BEN K et al, 2014 [20], HUNG JJ et al, 2003 [24]).

Regarding seizure semiology, the reported seizures were bilateral and symmetrical in $>87-90 \%$ of cases (UEMURA N et al, 2002 [4], RAM KIM B et al, 2018 [8], KIM G et al, 2016 [19]). Uemura et al. reported that $13 \%$ of patients had focal seizures with impaired awareness
(UEMURA N, 2002 [4]). Komori et al. described 19 clinical events in 10 patients, out of which 10 were focal seizures (KOMORI et al, 1995 [3]). Caraballo et al reported that in $68.5 \%$ of cases the seizures had a focal onset (CARABALLO RH et al, 2009 [25]). The seizures were mostly short ( $<5$ minutes/episode), although there were episodes that lasted about 15 minutes (UEMURA $\mathrm{N}$ et al, 2002 [4], RAM KIM B et al, 2018 [8], KAWANO G et al, 2007 [9]). In his observational study, Xiahong et al mentioned that $96.4 \%$ of convulsions lasted less than 5 minutes (MA XIAOHONG et al, 2018 [7]). Seizures usually occur in clusters with a frequency of about 1 to 4 episodes within $24 \mathrm{~h}$ (MA X et al, 2018 [7]) while other reports have shown a frequency of 1 to 8 times (UEMURA $\mathrm{N}$ et al, 2002 [4], KAWANO G et al, 2007 [9], VERROTTI A, 2011 [10], VERROTTI A et al, 2014 [17], HYUN S et al, 2015 [18], BEN K et al, 2014 [20], CARABALLO RH et al, 2009 [25], LEE EH and CHUNG S, 2013 [26], KOMORI H et al, 1995 [27]). Cluster seizures are more likely to be associated with noroviral gastroenteritis than with rotavirus infection $(79.5 \%$ vs $57.7 \%$ ) (RAM KIM B et al, 2018 [8]).

The interval between the onset of gastroenteritis symptoms and seizures ranges from 1 to 6 days (VERROTTI A et al, 2009 [12]). Xiaohong et al mentioned that convulsions occur during the first 2 days after the onset of clinical manifestations in $78.2 \%$ of cases (MA XIAOHONG et al, 2018 [7]). Kim et al. found that this interval is shorter in patients with norovirus, compared to rotavirus associated $\mathrm{CwG}(2.00 \pm 1.06$ vs. $2.58 \pm 1.21$ days, $\mathrm{P}=0.04$ ) (RAM KIM B et al, 2018 [8]). There is data showing patients can experience seizures before the onset of gastroenteritis symptoms (RAM KIM B et al, 2018 [8], HYUN S et al, 2015 [18], KOMORI H et al, 1995 [27]). Febrile seizures (FS) can also occur, considering the infectious underlying entities, and afebrile seizures tend to occur more frequently in patients with norovirus infection (CHEN S et al, 2009 [23], CHAN CV et al, 2011 [28]).

The mechanism is still unknown. CwG have only been reported in infants and young children. Abnormal electrolyte balance, dehydration and fever are possible mechanisms for seizures in children, yet in CwG they are normal, which suggests that other mechanisms are involved. Rotavirus was the most frequently detected microorganism in the stool specimens of patients with CwG, according to some authors, while others reported a greater incidence of convulsions associated with norovirus (UEMURA N et al, 2002 [4], RAM KIM B et al, 2018 [8], KAWANO G, 2007 [9], VERROTTI A, 2011 [10], VERROTTI A et al, 2009 [12], TANABE T et al, 2011 [13], LI T et al, 2014 [15], UEDA H et al, 2015 [16], HYUN S et al, 2015 [18], KIM G et al, 2016 [19], BEN K et al, 2014 [20], CASTELLAZZI L et al, 2016 [21], CHEN S et al, 2009 [23], LIN SC et al, 1996 [29]). Rotavirus was the most frequently involved pathogen in $\mathrm{CwG}$ before the vaccine was introduced and even after that there wasn't any decrease in $\mathrm{CwG}$ incidence. Some authors reported a selective interaction between rotavirus and neuronal cytoskeletal proteins (WECLEWICZ K et al, 1993 [30]). Nitric 
oxide seems to play a role in the pathophysiology of rotavirus associated convulsions. NSP4 (rotavirus nonstructural protein 4) is an enterotoxin that can cause neurotoxicity by cytokine dysregulation, neurotransmitter imbalance or direct viral invasion (LUAN S et al, 2019 [7]). Yeom et al suggested that the increased serum level of antiNSP4 immunoglobulin G (IgG) antibodies in patients with $\mathrm{CwG}$ have a protective role (SOOK J et al, 2017 [32]). Motomoya et al found decreased levels of serum sodium and chloride in patients with $\mathrm{CwG}$, suggesting that sodium channels are involved in the onset of seizures (MASASHI $M$ et al, 2009 [33]). Zifman et al tested the serum sodium levels in children with $\mathrm{CwG}$ and found that hyponatremia could affect seizure duration (ZIFMAN E et al, 2011 [34]). However, Kang et al. showed no significant difference in hyponatremia levels between convulsive and nonconvulsive groups (KANG B et al, 2013 [35]). Nowadays, the most frequently involved virus in the etiology of CwG is the norovirus (RAM KIM B et al, 2018 [8], HYUN S et al, 2015 [18], KIM G et al, 2016 [19]). The mechanism underlying the seizures is still undetermined and viremia has occasionally been documented in patients with seizures (KANG B et al, 2013 [35]). Other multiple viruses were also found to be associated with $\mathrm{CwG}$, such as sapovirus, adenovirus and coxsackie (KAWANO G, 2007 [9]).

The role of genetic involvement in the mechanism of CwG is not well understood, Khosroshahi et al showing a positive family history in $4 \%$ of patients (MEDICIA MC et al, 2010 [36]). Verrotti et al. also reported a family history of simple febrile seizures or epilepsy in first and second degree relatives of patients with CwG (VERROTTI A, 2011 [10]). Further studies are needed to determine the genetic susceptibility in patients with $\mathrm{CwG}$. However, racial differences suggest the involvement of genetic factors in the development of CwG. Ishii et al. demonstrated that PRRT2 gene variations are unlikely to be associated with the pathogenesis of CwG (KHOSROSHAHI et al, 2018 [37]). No mutations of other genes that can cause benign infantile epilepsy, such PRRT2 or SCN1A have been reported in patients with CwG (KHOSROSHAHI et al, 2018 [37], ISHII A et al, 2013 [38]).

In the majority of cases, the investigations in children with $\mathrm{CwG}$ show no abnormalities in biochemistry tests, serum electrolytes, blood count or cerebrospinal fluid analysis (UEMURA N et al, 2002 [4], VERROTTI A, 2011 [10]), although, there are some studies that postulate the association of high serum uric acid in patients with $\mathrm{CwG}$ (RAM KIM B et al, 2018 [8], ISHII A et al, 2013 [38]). Because the diagnosis is established on clinical grounds, paraclinical investigations are not always necessary. Reports of ictal EEGs are very rare. The interictal EEG is normal in the majority of cases. However, sometimes it can show slow waves or focal sharp/spikes abnormalities (UEMURA N et al, 2002 [4], NARCHI H, 2004 [6], RAM KIM B et al, 2018 [8], KAWANO G et al, 2007 [9], VERROTTI A et al, 2011 [10], VERROTTI A et al, 2009 [12], LI T et al, 2014 [15], UEDA H et al, 2015 [16], HYUN S et al, 2015 [18], BEN K et al, 2014 [20], CASTELLAZZI
L et al, 2016 [21], CHEN S et al, 2009 [23], HUNG JJ et al, 2003 [24], CARABALLO RH et al, 2009 [25], KOMORI H et al, 1995 [27], WENG WC et al, 2010 [39]). Kim et al reported that posterior slowing was observed more frequently in patients with norovirus-associated $\mathrm{CwG}$ $(34.9 \%)$ vs rotavirus (11.5\%) (RAM KIM B et al, 2018 [8]). He also reported normal brain imaging scans in all patients. The computed tomography scans are usually normal (UEMURA N et al, 2002 [4], NARCHI H, 2004 [6]). Most patients have a good prognosis without later developing epilepsy. The optimal treatment for clustered seizures in CWG is uncertain. Usually, the treatment is not required as seizures are short-lasing ( $<5$ minutes) and end within the first $24 \mathrm{~h}$ from the onset (UEMURA $\mathrm{N}$ et al, 2002 [4], KAWANO G et al, 2007 [9], OKUMURA A et al, 2004 [22]).

Diazepam is not recommended when treating $\mathrm{CwG}$, as the majority of patients still have seizures after its administration (YOO IH et al, 2019 [40]). Carbamazepine can be a useful antiepileptic drug in a low dose ( $5 \mathrm{mg} / \mathrm{kg} /$ day), one daily dose for 1 to 3 days (OMATA T et al, 2004 [31]); Lidocaine can also be an effective drug in the cessation of seizures (OKUMURA A et al, 2004 [22]). Even so, most studies showed that seizures did not cease after administration of any antiepileptic drug (UEMURA N et al, 2002 [4], VERROTTI A et al, 2009 [12]).

Long-term treatment is not required for these patients (NARCHI H, 2004 [6]).

\section{Case Report}

We present the case of a three-year-old male patient with no family history of epilepsy. His birth history was unremarkable and his Apgar score was 9. He had a normal psychomotor development except for a mild language acquisition delay.

The onset of seizures was at 16 months of age, with a cluster of short-lasting bilateral tonic-clonic afebrile seizures over 24 hours, during an acute gastroenteritis episode. The interval between diarrhea and the onset of seizures was 48 hours. The patient presented with a single episode of fever $\left(39^{\circ} \mathrm{C}\right)$ within 24 hours before the onset of seizures. He experienced four afebrile seizures, lasting about 3-4 minutes. Both Campylobacter jejuni and adenovirus antigens were isolated from stool samples. Blood workup was unremarkable and serum electrolytes were normal. EEG and cranial computed tomography were normal. After the third and the forth episodes he received intrarectal Diazepam, and he was admitted in the intensive care unit due to altered consciousness.

After four months, the patient experienced another gastroenteritis episode, during which he had a second afebrile seizure cluster ( 2 episodes), lasting $<5$ minutes. Five days before the onset of seizures he had rhinorrhea and productive cough, three days before he presented diarrhea. A few days later he experienced another cluster of seizures ( 2 episodes), with similar clinical characteristics. The PCR assay in stool was positive for astrovirus, rotavirus and norovirus. The brain computed tomography and lumbar puncture were normal. The interictal EEG showed no 
abnormalities. Due to high guardian anxiety regarding seizure recurrence, antiepileptic treatment with Levetiracetam was introduced. At the 6 and 12-month follow-ups he was seizure free.

The patient had normal reach of motor milestones, but poor expressive language development and a DQ of 65 . Furthermore, he had particular facial features (downslanting palpebral fissures, hypertelorism), $2^{\text {nd }}$ and $3^{\text {rd }}$ toe syndactyly and macrocephaly.

The 8-h EEG recording including a waking and sleep period revealed no significant epileptiform discharges. His cerebral 3T MRI was normal. The audiogram was normal.

\section{Material and Methods}

Due to the atypical clinical presentation and the fact that he is the couple's first child, genetic testing Whole Exome Sequencing (WES) was performed in order to verify possible genetic causes and to establish familial recurrence risk. Blood was obtained after his parents had signed an informed consent.

\section{Results}

This revealed a heterozygous variant, c.965C $>\mathrm{T}$, in NTRK2 gene, classified as a variant of uncertain significance, VUS. Therefore, parental carrier testing was necessary in order to establish whether this variant was inherited or "de novo", and also for familial segregation studies. The parental analysis identified that this variant was inherited from an asymptomatic mother. According to the laboratory database (CentoMD 5.3), this variant was reported as well in another family, and was also inherited from an asymptomatic parent. Therefore, this variant was reclassified as likely benign. In this context, the previous genetic finding is not considered to have clinical relevance.

\section{Discussions}

Previous cases of convulsions associated with gastroenteritis concurred that they represent a benign condition with a good prognosis. Yet, there have been no recent advances in finding a possible genetic etiology, considering that the underlying mechanism is unknown and that most of the cases have been reported in Asia.

The NTRK2 gene variants are associated with early infantile epileptic encephalopathy type 58 as well as obesity, mood disorders and severe developmental delay. Even if our patient's variant of NTRK2 gene was classified as likely benign, the clinical context with developmental delay and dysmorphic features suggests a possible genetic cause, still unidentified. Further comprehensive re-evaluation of sequencing data, possibly with additional clinical information, is advised.

\section{Conclusions}

Recognition of this type of seizure is mainly clinical. Paraclinical investigations such as EEG and MRI need to be performed for a correct differential diagnosis. Careful examination and history taking is needed in order to identify possible underlying genetic syndromes, predominantly in children with dysmorphic features and/or cognitive, language delay or psychiatric comorbidities. At this point, there is a lack of evidence regarding the use of long-term anticonvulsivant therapy in these circumstances.

Prospective randomized case-control studies are necessary to establish the therapeutic management in these patients, considering that the optimal treatment of cluster convulsions associated with gastroenteritis has not been defined yet. Hence, it is postulated that genetic factors may be involved in the pathogenesis of CwG. Genetic testing may be considered in more complex cases, with developmental delay and dysmorphic features.

\section{Conflict of Interest}

The authors declare that there is no conflict of interest.

\section{References}

1. MOROOKA K. Convulsions and mild diarrhea (in Japanese). Shonika (Tokyo). 1982; 23:131-7.

2. NISHIMURA S, USHIJIMA H, SHIRAISHI H, KANAZAWA C, et al. Detection of rotavirus in cerebrospinal fluid and blood of patients with convulsions and gastroenteritis by means of the reverse transcription polymerase chain reaction. Brain Dev. 1993; 15(6):457-9. DOI: 10.1016/0387-7604(93)90088-p

3. KOMORI $\mathrm{H}$, et al. Benign convulsions with mild gastroenteritis: a report of 10 recent cases detailing clinical varieties. Brain Dev. 1995; 17(5):334-7. DOI: 10.1016/0387-7604(95)00074-L

4. UEMURA N, OKUMURA A, NEGORO T, WATANABE K. Clinical features of benign convulsions with mild gastroenteritis. Brain Dev. 2002; 24(8):745-9. DOI: 10.1016/s0387-7604(02)00097-9

5. IYADURAI S, TROESTER M, HARMALA J, BODENSTEINER J. Benign Afebrile Seizures in Acute Gastroenteritis: Is Rotavirus the Culprit? J Child Neurol. 2007 Jul; 22(7):887-90. DOI: 10.1177/0883073807304703

6. NARCHI H. Benign afebrile cluster convulsions with gastroenteritis: an observational study. BMC Pediatr. 2004 Dec; 4(1):2. DOI: 10.1186/1471-2431-4-2

7. MA X, LUAN S, ZHAO Y, LV X, ZHANG R. Clinical characteristics and follow-up of benign convulsions with mild gastroenteritis among children. Med. 2019 Jan; 98(2):e14082. DOI: 10.1097/MD.0000000000014082

8. RAM KIM B, EUN CHOI G, OK KIM Y, JI KIM M, et al. Incidence and characteristics of norovirus-associated benign convulsions with mild gastroenteritis, in comparison with rotavirus ones. Brain Dev. 2018; 40(8):699706. DOI: 10.1016/j.braindev.2018.04.001

9. KAWANO G, OSHIGE K, SYUTOU S, KOTEDA Y, et al. Benign infantile convulsions associated with mild gastroenteritis: a retrospective study of 39 cases including virological tests and efficacy of anticonvulsants. Brain Dev. 2007 Nov; 29(10):617-22. DOI: 10.1016/j.braindev. 2007.03.012

10. VERROTTI A, NANNI G, AGOSTINELLI S, PARISI P, et al. Benign convulsions associated with mild gastroenteritis: A multicenter clinical study. Epilepsy Res. 2011; 93(2-3):107-14. DOI: 10.1016/j.eplepsyres.2010.11.004. 
11. FANG $\mathrm{Y}, \mathrm{CHEN} \mathrm{E}, \mathrm{WANG} \mathrm{CY}, \mathrm{CHIU} \mathrm{CH}$, et al Molecular epidemiology and clinical characteristics of norovirus gastroenteritis with seizures in children in Taiwan, 2006-2015. Med. 2019; 98(49):e17269. DOI: 10.1097/MD.0000000000017269

12. VERROTTI A, TOCCO AM, COPPOLA GG, ALTOBELLI E, et al. Afebrile benign convulsions with mild gastroenteritis: A new entity? Acta Neurol Scand. 2009; 120(2):73-79. DOI: 10.1111/j.1600-0404.2008.01154.x.

13. TANABE T, OKUMURA A, KOMATSU M, KUBOTA T,et al. Clinical trial of minimal treatment for clustering seizures in cases of convulsions with mild gastroenteritis. Brain Dev. 2011; 33(2):120-124. DOI: 10.1016/j. braindev.2010.02.007

14. CHEN B, CHENG M, HONG S, LIAO S, et al. Clinical outcome of recurrent afebrile seizures in children with benign convulsions associated with mild gastroenteritis. Seizure Eur J Epilepsy, 2018 Aug; 60:110-4. DOI: 10.1016/j.seizure.2018.05.020

15. LI T, HONG S, PENG X, CHENG M, et al. Benign infantile convulsions associated with mild gastroenteritis : An electroclinical study of 34 patients. Seizure Eur J Epilepsy 2014; 23(1):16-19. DOI: 10.1016/j.seizure. 2013.09.003

16. UEDA H, TAJIRI H, KIMURA S, ETANI Y, et al. Clinical characteristics of seizures associated with viral gastroenteritis in children. Epilepsy Res. 2015; 109:14654. DOI: $10.1016 /$ j.eplepsyres.2014.10.021

17. VERROTTI A, MOAVERO R, VIGEVANO F, CANTONETTI L, et al. Long-term follow-up in children with benign convulsions associated with gastroenteritis. Eur J Paediatr Neurol. 2014; 39(0):2-7. DOI: 10.1016/ j.ejpn.2014.04.006

18. HYUN S, OK Y, KYUL H, SUNG H, et al. Incidence of benign convulsions with mild gastroenteritis after introduction of rotavirus vaccine. Brain Dev. 2015; 37(6):625-30. DOI: 10.1016/j.braindev.2014.09.002

19. KIM G, BYEON JH, LEE D, JEONG HJ, et al. Norovirus in benign convulsions with mild gastroenteritis. Ital $J$ Pediatr. 2016; 42(94):1-5. DOI: 10.1186/s13052-0160303-2

20. BEN K, YOUNG SE K. Benign convulsion with mild gastroenteritis. Korean J Pediatr. 2014; 57(7):304-9. DOI: $10.3345 / \mathrm{kjp} .2014 .57 .7 .304$

21. CASTELlAZZI L, PRINCIPI N, AGOSTONI C, ESPOSITO S. Benign convulsions in children with mild gastroenteritis. Eur J Paediatr Neurol. 2016; 20(5):690695. DOI: 10.1016/j.ejpn.2016.05.014

22. OKUMURA A, UEMURA N, NEGORO T, WATANABE K. Efficacy of antiepileptic drugs in patients with benign convulsions with mild gastroenteritis. Brain Dev. 2004; 26(3):164-7. DOI: 10.1016/S0387-7604(03)00121-9

23. CHEN S, TSAI C, LAI M, CHEN C, et al. Norovirus Infection as a Cause of Diarrhea-Associated Benign Infantile Seizures. Clin Infect Dis. 2009; 48(7):849-55. DOI: $10.1086 / 597256$

24. HUNG JJ, WEN HY, YEN MH et al. Rotavirus gastroenteritis associated with afebrile convulsion in children: clinical analysis of 40 cases. Chang Gung Med J. 2003; 26(9):654-9. PMID: 14651163

25. CARABALLO RH, GANEZ L, LOSSANTOS C DE, ESPECHE A, et al. Benign infantile seizures with mild gastroenteritis: study of 22 patients. Seizure. 2009; 18(10):686-9. DOI: 10.1016/j.seizure.2009.09.006
26. LEE EH, CHUNG S. A comparative study of febrile and afebrile seizures associated with mild gastroenteritis. Brain Dev. 2013; 35(7):636-40. DOI: 10.1016/j.braindev. 2012.09.014

27. KOMORI H, WADA M, ETO M, OKI H, et al. Benign convulsions with mild gastroenteritis: a report of 10 recent cases detailing clinical varieties. Brain Dev. 1995; 17(5): 334-7. DOI: 10.1016/0387-7604(95)00074-L

28. CHAN CV, CHAN CD, MA C, CHAN H. Norovirus as cause of benign convulsion associated with gastroenteritis. 2011; 47(6):373-7. DOI: 1 10.1111/j.14401754.2010.01986.x

29. LIN SC, HSU HY, WANG PJ, LEE CN, et al. Rotavirus gastroenteritis associated with afebrile seizure in childhood. Zhonghua Minguo xiao er ke yi xue hui za zhi [Journal]. 1996; 37(3):204-7. PMID: 8755176

30. WECLEWICZ K, KRISTENSSON K, GREENBERG HB, SVENSSON L. The endoplasmic reticulum-associated VP7 of rotavirus is targeted to axons and dendrites in polarized neurons. J Neurocytol. 1993 Aug; 22(8):61626. DOI: $10.1007 / \mathrm{BF} 01181488$

31. MATSUFUJI H, ICHIYAMA T, ISUMI H, FURUKAWA S. Low-dose carbamazepine therapy for benign infantile convulsions. Brain Dev. 2005 Dec; 27(8):554-7. DOI: 10.1016/j.braindev.2005.01.005

32. SOOK J, KIM Y, JUN J, JUNG H, et al. NSP4 antibody levels in rotavirus gastroenteritis patients with seizures. Eur J Paediatr Neurol. 2017; 21(2):367-73. DOI: 10.1016/j.ejpn.2016.10.006

33. MOTOYAMA M, ICHIYAMA T, MATSUSHIGE T, KAJIMOTO M, et al. Clinical characteristics of benign convulsions with mild gastroenteritis. Epilepsy Currents. J Child Neurol. 2009; 24(5):257-61. DOI: 10.1097/MD. 0000000000014082

34. ZIFMAN E, ALEHAN F, MENASCU S, HAR-GIL M, et al. Clinical Characterization of Gastroenteritis-Related Seizures in Children : Impact of Fever and Serum Sodium Levels. J Child Neurol. 2011; 26(11):1397-1400. DOI: 10.1177/0883073811409222

35. KANG B, HYUN D, JIN Y, KWAN B, et al. Comparison between febrile and afebrile seizures associated with mild rotavirus gastroenteritis. Seizure Eur J Epilepsy. 2013; 22(7):560-4. DOI: 10.1016/j.seizure.2013.04.007

36. MEDICIA MC, ABELLIA LA, DODIB I, DETTORIA G, et al. Norovirus RNA in the blood of a child with gastroenteritis and convulsions - A case report. J Clin Virol. 2010; 48(2):147-9. DOI: 10.1016/j.jcv.2010.03.001

37. KHOSROSHAHI N, RAHBARIMANESH A, BOROUJENI FA, ESKANDARIZADEH Z, et al. Afebrile Benign Convulsion Associated With Mild Gastroenteritis : A Cohort Study in a Tertiary Children Hospital. Child Neurol Open. 2018; 5:1-5. DOI: 10.1177/2329048X18773498

38. ISHII A, YASUMOTO S, IHARA Y, INOUE T, et al. Genetic analysis of PRRT2 for benign infantile epilepsy, infantile convulsions with choreoathetosis syndrome, and benign convulsions with mild gastroenteritis. Brain Dev. 2013; 35(6):524-30. DOI: 10.1016/j.braindev.2012.09.006

39. WENG WC, HIROSE S, LEE WT. Benign convulsions with mild gastroenteritis: Is it associated with sodium channel gene SCN1A mutation? J Child Neurol. 2010; 25(12):1521-4. DOI: $10.1177 / 0883073810370898$

40. OMATA T, TAMAI K, KUROSAKI A. Clinical study of convulsions with mild gastroenteritis. Nihon Shonika Gakkai Zasshi (Tokyo). 2004; 26:164-7. DOI: 10.1097/ MD.0000000000014082 